\title{
ICNP ${ }^{\circledR}$ terminology subset for the care of people with heart failure
}

\author{
Subconjunto terminológico da CIPE ${ }^{\circledR}$ para o cuidado à pessoa com insuficiência cardíaca \\ Subconjunto terminológico de la CIPE para la atención de personas con insuficiencia cardíaca
}

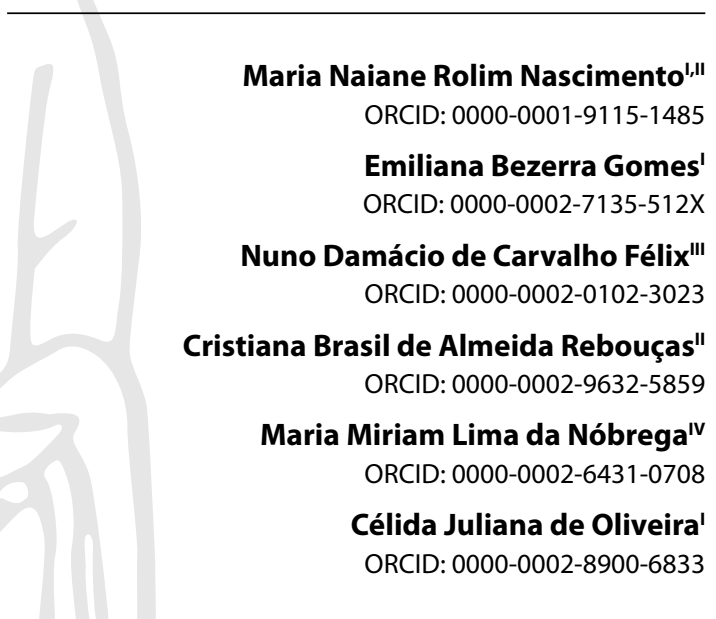

'Universidade Regional do Cariri. Crato, Ceará, Brazil. "Universidade Federal do Ceará. Fortaleza, Ceará, Brazil.

"' Universidade Federal do Recôncavo da Bahia.

Santo Antônio de Jesus, Bahia, Brazil.

"Universidade Federal da Paraíba. João Pessoa, Paraíba, Brazil.

How to cite this article:

Nascimento MNR, Gomes EB, Félix NDC, Rebouças CBA, Nóbrega MML, Oliveira CJ. ICNP® terminology subset for the care of people with heart failure.

Rev Bras Enferm. 2022;75(2):e20210196. https://doi.org/10.1590/0034-7167-2021-0196

Corresponding author:

Maria Naiane Rolim Nascimento

E-mail: naianerolim@hotmail.com

EDITOR IN CHIEF: Antonio José de Almeida Filho ASSOCIATE EDITOR: Fátima Helena Espírito Santo

\section{ABSTRACT}

Objective: to develop an ICNP® terminology subset for the care of people with heart failure. Methods: this is a methodological study, which used the theoretical framework of the MidRange Nursing Theory for Cardiovascular Rehabilitation, with the steps: Construction of nursing diagnoses/outcomes and interventions statements and Cross-mapping of statements constructed. Results: forty-two diagnosis/outcome statements and 179 nursing intervention statements were constructed, organized based on five theory concepts, with a higher prevalence of statements related to "Rehabilitative care", "Psychosocial support for patients and families" and "Supervised cardiovascular rehabilitation program". Final considerations: it was possible to build nursing diagnosis/outcome and intervention statements for developing a terminology subset for the care of people with heart failure, based on the chosen theory. Descriptors: Cardiovascular Nursing; Cardiac Rehabilitation; Heart Failure; Nursing Care; Standardized Nursing Terminology.

\section{RESUMO}

Objetivo: elaborar um subconjunto terminológico da CIPE ${ }^{\oplus}$ para o cuidado de enfermagem à pessoa com insuficiência cardíaca para a atenção hospitalar. Métodos: estudo metodológico, que utilizou o referencial teórico da Teoria de Enfermagem de Médio Alcance para Reabilitação Cardiovascular, com as etapas: Construção dos enunciados de diagnósticos/resultados e intervenções de enfermagem e Mapeamento cruzado dos enunciados construídos. Resultados: foram construídos 42 enunciados de diagnósticos/resultados e 179 enunciados de intervenções de enfermagem, organizados com base em cinco conceitos da teoria destacando-se com maior prevalência de enunciados relacionados ao "Cuidado reabilitador", ao "Apoio psicossocial ao paciente e a família" e ao"Programa de reabilitação cardiovascular supervisionado". Considerações finais: foi possível construir enunciados de diagnósticos/ resultados e intervenções de enfermagem para a elaboração de subconjunto terminológico para o cuidado à pessoa com insuficiência cardíaca, com base na teoria eleita.

Descritores: Enfermagem Cardiovascular; Reabilitação Cardíaca; Insuficiência Cardíaca; Cuidados de Enfermagem; Terminologia Padronizada em Enfermagem.

\section{RESUMEN}

Objetivo: desarrollar un subconjunto terminológico de la CIPE ${ }^{\circledast}$ para la atención de enfermería a las personas con insuficiencia cardíaca. Métodos: estudio metodológico, que utilizó el marco teórico de la Teoría de Enfermería de Rango Medio para la Rehabilitación Cardiovascular, con los pasos: Construcción de enunciados de diagnósticos/resultados e intervenciones de enfermería y Mapeo cruzado de enunciados construido. Resultados: se construyeron 42 enunciados de diagnósticos/resultados y 179 enunciados de intervenciones de enfermería, organizados en base a cinco conceptos de la teoría, con mayor prevalencia de enunciados relacionados con "Atención rehabilitadora", "Apoyo psicosocial al paciente y la familia" y el "Programa de rehabilitación cardiovascular supervisado". Consideraciones finales: fue posible construir enunciados de diagnósticos/resultados e intervenciones de enfermería para el desarrollo de un subconjunto terminológico para el cuidado de personas con insuficiencia cardíaca, basado en la teoría elegida. Descriptores: Enfermería Cardiovascular; Rehabilitación Cardiaca; Insuficiencia Cardíaca; Atención de Enfermería; Terminología Normalizada de Enfermería. 


\section{INTRODUCTION}

Heart failure is a health priority defined as a clinical syndrome of a systemic nature, which causes fluid overload or inadequate blood supply to meet tissue metabolic needs, with different etiologies, usually progressive and resulting from other cardiovascular problems ${ }^{(1)}$. It is characterized as a public health problem, affecting approximately $2 \%$ of the world population between 40 and 49 years old and $5 \%$ between 60 and 69 years old ${ }^{(2)}$, which requires immediate and precise care from the nursing team, based on the control of long-term affection and cardiac rehabilitation.

Nursing acts based on its own language, which acts to identify clinical indicators that reflect diagnosis concepts/ nursing outcomes that allow the establishment of nursing interventions that must be resolute, based on critical thinking and clinical reasoning ${ }^{(3)}$. Given this context, the importance of using nursing terminologies is highlighted, which standardize the language, assisting in the systematization of care ${ }^{(4)}$, in addition to demonstrating the irreplaceable importance and role of nursing in the health area.

In this scenario, the International Classification for Nursing Practice $\left(\right.$ ICNP $^{\circ}$ ) stands out, the only international nursing terminology recognized by the World Health Organization ${ }^{(5)}$ and holder of a unified language that enables creating diagnoses, outcomes, and interventions of nursing as interrelated and interdependent elements.

For the development of a nursing language from the ICNP ${ }^{\circ}$ for a specific population or health priority, it is necessary to build terminology subsets, a strategy of the International Council of Nurses $(\mathrm{ICN})^{(6)}$, and currently, a trend in the development of subsets ${ }^{(7-8)}$, containing nursing diagnoses, outcomes and interventions based on the identification of the needs of people being cared for.

Thus, we highlight the first terminology subset developed at the Brazilian ICNP ${ }^{\circ}$ Center - at the time the ICNP ${ }^{\circ}$ Catalog - which built nursing diagnosis/outcome and intervention statements for people with heart failure, using the ICNP', version 1.0 and the pathophysiology model of previous health condition ${ }^{(9)}$. We emphasize the updating of updated standards for the development of terminology subsets and the evolution of the classification system, with the inclusion of new pre-coordinated concepts.

Thus, the literature ${ }^{(10)}$ states that there is a shortage when it comes to a specific validated standardized terminology, aimed at nursing care for people with heart failure, as an affection that involves an essential system to life and that demands targeted and accurate care, there is a concern to compose an information system that organizes nursing language in care internationally and universally, enabling better execution of practice. Therefore, the relevance of this study lies in the perspective of expanding another ${ }^{(9)}$.

\section{OBJECTIVE}

To develop an ICNP ${ }^{\circ}$ terminology subset for the care of people with heart failure.

\section{METHOD}

\section{Ethical aspects}

The study was submitted to Plataforma Brasil, with favorable consideration by the Institutional Review Board of Universidade Regional do Cariri.

\section{Theoretical-methodological framework}

The Medium-Range Nursing Theory for Cardiovascular Rehabilitation (Nur-MRT CVR) ${ }^{(11)}$ was used, based on five of its 11 concepts, to compose the construction, organization and subsequent elaboration of an ICNP ${ }^{\circ}$ terminology subset, namely: "Rehabilitative care”,"Educational process", "Psychosocial support for patients and families", "Supervised cardiovascular rehabilitation program", and "Exercise-based therapy". The choice of the five concepts is justified because of their relationship with nursing in terms of direct care to the person being cared for, which would not be possible with the other concepts present in the theory.

\section{Study design and period}

This is a methodological study, based on the adaptation of STROBE for cross-sectional studies ${ }^{(12)}$, which makes up a master's thesis of the Graduate Program in Nursing at Universidade Regional do Cariri, from February 2018 to March 2020.

Two steps were carried out based on the ICN recommendations ${ }^{(6)}$ and on the steps for the construction ICNP ${ }^{\circ}$ terminology subsets ${ }^{(4)}$ : 1) Construction of nursing diagnosis/outcomes and intervention statements; 2) Cross-mapping of statements built with those of the first subset prepared based on ICNP', version 1.0 and with those of the ICNP $^{\circ}$, version 2019-2020.

\section{Methodological procedure}

Based on the specialized nursing terminology constructed, 333 unique primitive concepts were obtained ${ }^{(13)}$, making it possible to construct nursing diagnosis/outcome and intervention statements, following the ICN and the ISO 18.104:2014 recommendations ${ }^{(6,14)}$. In the second stage, the nursing diagnosis/ outcomes statements constructed in this study were mapped with those constructed based on the ICNP', version 1.0, in addition to the concepts of ICNP', version 2019-2020(15), through Excel for Windows 2013 spreadsheets, crossed by the Access for Windows ${ }^{\circledR} 2013$ program, in order to verify the consistency of these statements.

Then, the same mapping process was carried out with the nursing intervention statements constructed in the current study with the statements constructed from ICNP', version 1.0 and also with the concepts of nursing interventions from ICNP', version 2019-2020. Nursing diagnosis/outcome and non-constant intervention statements were also analyzed for similarity and scope in relation to the concepts contained in the ICNP'(15); then, they were tabulated in the Excel for Windows ${ }^{\circ}$ program and organized based on the five concepts selected from the chosen theory ${ }^{(11)}$. 
Based on constructed statements, the mapping was chosen prior to content assessment, given the fact that it is relevant to unify diagnosis, outcome and intervention statements constructed in this study with those constructed based on the ICNP', version 1.0 for its subsequent submission to the content evaluation process.

\section{Data organization and analysis}

The findings were organized based on Excel for Windows ${ }^{\circledR}$ spreadsheets and presented descriptively and in charts, in a systematic way, from the five concepts selected from the theory used, discussed according to literature in the area.

\section{RESULTS}

Forty-two nursing diagnosis/outcome statements aimed at nursing care for people with heart failure were constructed, organized based on five concepts of the MRT, namely: "Rehabilitative care" ( $n=15)$, "Educational process" $(n=03)$, "Psychosocial support for patients and families" $(\mathrm{n}=08)$, "Supervised cardiovascular rehabilitation program" $(n=13)$, and "Exercise-based therapy" ( $n=03)$ (Chart 1).

As for nursing interventions, 179 unique statements were constructed for nursing care for people with heart failure, also organized based on the five concepts of the MRT, with the following distribution: "Rehabilitative care" $(n=87)$, "Educational process" ( $n=18)$, "Psychosocial support for patients and families" ( $n=35)$, "Supervised cardiovascular rehabilitation program" $(n=29)$, and "Exercise-based therapy" $(n=10)$ (Chart 1). It should be noted that, for the construction of some nursing intervention statements, specifier terms were used that are not included in the ICNP', version 2019-2020, nor in the standardized terminology constructed in this study, with the terms contained in the classification system followed by a code.

Chart 1 - Nursing diagnoses/outcomes statement constructed for nursing care for people with heart failure constructed and organized based on MediumRange Nursing Theory for Cardiovascular Rehabilitation (Nur-MRT CVR), Crato, Ceará, Brazil, 2019

\begin{tabular}{|c|c|}
\hline & REHABILITATIVE CARE \\
\hline & Nursing Diagnosis Statement \\
\hline & red Cardiac Output (10025557) \\
\hline & noea (Specify Type) (10029433) \\
\hline & Specify Type) (10023130) \\
\hline & a (Specify Degree) \\
\hline & ased Body Mass Index \\
\hline & ure Ulcer (Specify Stage) (10025798) \\
\hline & (10000859) \\
\hline & ctive Tissue Perfusion (10001344) \\
\hline & ctive Peripheral Tissue Perfusion (10044239) \\
\hline & r Aspiration (10015024) \\
\hline & or Cardiogenic Shock \\
\hline & or Infection (10015133) \\
\hline & or Deep Vein Thrombosis (10027509) \\
\hline & (10047143) \\
\hline & volaemia (10042012) \\
\hline & Nursing Intervention Statement \\
\hline $\begin{array}{l}1 . \\
2 . \\
3 . \\
4 . \\
5 . \\
6 . \\
7 . \\
8 . \\
9 . \\
10 \\
11 \\
12 \\
13 \\
14 \\
15 \\
16 \\
17 \\
18 \\
19 \\
20 \\
21\end{array}$ & $\begin{array}{l}\text { Administering and monitoring oxygen therapy; } \\
\text { Administering nutritional supplement (10037037); } \\
\text { Suctioning the airway (10044890); } \\
\text { Listening to and assess intestinal noises daily; } \\
\text { Listening to heart rate paying attention to the presence of 3rd heart sound; } \\
\text { Listening to breathing noises before and after aspiration; } \\
\text { Assessing the cause of impaired sleep pattern; } \\
\text { Assessing oral cavity condition; } \\
\text { Assessing nutritional status; } \\
\text { Assessing discomfort (type, orientation, intensity); } \\
\text { Assessing pain (presence, orientation, onset, duration, intensity); } \\
\text { Assessing intestinal eliminations (frequency, quantity, fecal aspects); } \\
\text { Assessing pressure ulcer staging; } \\
\text { Assessing previous pain experiences, including individual and family history of chronic pain or resulting disability; } \\
\text { Assessing and monitoring the presence and degree of edema; } \\
\text { Assessing and monitoring pulmonary artery pressure; } \\
\text { Assessing and monitoring central venous pressure or right atrial pressure; } \\
\text { Assessing and monitoring signs of dehydration (decreased skin turgor, dry mucosa); } \\
\text { Assessing and monitoring person's level of consciousness; } \\
\text { Assessing and monitoring skin (color, temperature, pain, edema, sensitivity, humidity, signs of infection); } \\
\text { Assessing and monitoring cough reflex, nausea and ability to swallow; }\end{array}$ \\
\hline
\end{tabular}


Chart 1

\section{Nursing Intervention Statement}

22. Monitoring vital signs (10032113);

23. Assessing urinary bladder functioning and integrity;

24. Assessing body mass index;

25. Assessing dietary fiber intake;

26. Assessing the lesion (degree, color, secretion, foul odor, pain, temperature);

27. Assessing upper and lower limbs (temperature, color, pulse rate);

28. Assessing moving the pain/discomfort to other locations;

29. Assessing the need for airway aspiration;

30. Assessing the need for wound dressing and coverage;

31. Assessing tissue perfusion;

32. Monitoring weight (10032121);

33. Assessing the presence of flatus;

34. Assessing oral problems that make eating and chewing difficult (prosthesis, wound);

35. Evaluating response to fluid therapy (10007176)

36. Interpreting arterial blood gas result (10010503);

37. Assessing signs of pulmonary edema (respiratory rate, sputum);

38. Assessing situations that cause discomfort;

39. Assessing type of dyspnea (night, intermittent, decubitus, at rest):

40. Assessing cough (sputum, discharge);

41. Catheterising urinary bladder (10030884);

42. Determining person's degree of dependence;

43. Determining degree of jugular vein distension;

44. Implementing enteral feeding (10046178);

45. Implementing artificial airway;

46. Investigating person's food preferences;

47. Washing hands before and after care;

48. Keeping person's head sideways;

49. Keeping person on bed rest;

50. Maintaining airway clearance (10037351)

51. Monitoring fasting person's abdominal circumference daily;

52. Monitoring decreased mobility in bed;

53. Monitoring urinary elimination (frequency, quantity, color, pain and foul odor);

54. Monitoring electrolyte balance;

55. Monitoring fluid balance, if greater than 2.5 liters;

56. Monitoring fluid balance, if less than 2.5 liters;

57. Monitoring fluid balance (10040852);

58. Monitoring degree of urinary bladder distension;

59. Monitoring blood oxygen saturation using pulse oximeter (10032047);

60. Monitoring sedation;

61. Offering small portions of meal often;

62. Offering drink (10050313):

63. Placing person on the bed with a raised headboard $\left(30^{\circ}, 45^{\circ}\right.$ or $\left.60^{\circ}\right)$;

64. Preventing injury during transfer technique (elevation);

65. Preventing spontaneous extubation (fix artificial airway with adhesive tape);

66. Providing food not accompanied by liquids;

67. Providing food with a high nutritional index;

68. Providing oral hygiene in bed every 6 hours;

69. Providing decubitus change every 2 hours;

70. Use transfer technique (10041135);

71. Performing physical examination of the chest (inspection, palpation, percussion and auscultation);

72. Performing abdominal physical examination (inspection, auscultation, percussion and palpation);

73. Rotating venipuncture site;

74. Recording sleep pattern in hours;

75. Nighttime fluid restriction;

76. Liquid restriction or supply;

77. Supervising insertion site of invasive devices (temperature, coloration, pain, secretion)

78. Wound dressing change (10045131);

79. Wound dressing change (10045131)

80. Use pain scales (verbal, facies, visual, numerical);

81. Wearing gloves according to standard precautions;

82. Use antimicrobial soap for hand hygiene;

83. Use aseptic technique (10041784);

84. Measuring height (10037000);

85. Checking and monitoring body temperature of the lower limbs;

86. Checking for residues from the nasogastric catheter or gastrostomy and irrigate every $4-6$ hours during continuous feeding and before intermittent feeding; 87. Checking residual enteral catheter volume;

\section{EDUCATIONAL PROCESS}

\section{Nursing Diagnosis Statement}

Conflicting Attitude Toward Medication Management (10022299)

Self Care Deficit (10023410)

Impaired Family/Caregiver's Ability to Manage Care 
Chart 1

\section{Nursing Intervention Statement}

88. Assessing person's knowledge about disease and treatment;

89. Encouraging person's autonomy in self-care, according to the degree of ability;

90. Facilitating person's ability to communicate conflicts in medication management;

91. Informing medication side effect;

92. Explaining to person/family/caregiver the causes of fatigue;

93. Teaching family/caregiver about the importance of stimulating the person's self-care;

94. Teaching family /caregiver about post-discharge care in managing the disease;

95. Teaching family/caregiver about illness and treatment;

96. Teaching family about treatment regimen (10024656);

97. Teaching about eating not accompanied by liquids;

98. Teaching about procedures, including sensations that the person can experience during procedures;

99. Teaching about moisturizer use;

100. Teaching breathing technique (10039213);

101. Provide an explanation about care to be performed;

102. Teaching pain (10039115);

103. Providing routine times for administering medications together with the person;

104. Providing techniques to minimize medication side effects (relaxation, rest, schedule);

105. Strengthening communication about disease and treatment;

PSYCHOSOCIAL SUPPORT FOR PATIENTS AND FAMILIES

Nursing Diagnosis Statement

Spiritual Distress (10018583)

Anxiety (10000477)

Situational Low Self Esteem (10000844)

Conflicting Spiritual Belief (10022769)

Hopelessness (10000742)

Unfavorable Religious Coping

Lack of Family Support (10022473)

Intervention Statement

Fear (10000703)

\section{Nursing Intervention Statement}

106. Helping to identify situations that cause anxiety;

107. Helping to identify situations that cause hopelessness;

108. Helping to identify situations that cause fear;

109. Assessing anxiety level;

110. Encouraging Bible reading;

111. Promoting acceptance of health status (10037783);

112. Teach relaxation techniques (reading, music therapy);

113. Facilitating person's ability to communicate needs related to self-esteem;

114. Facilitating person's ability to communicate needs related to spiritual demands;

115. Facilitating person's ability to communicate feelings related to hospitalization;

116. Facilitating family/caregiver's ability to communicate needs related to care management;

117. Facilitating family/caregiver's ability to communicate feelings related to hospitalization;

118. Identifying obstruction to communication (10009683);

119. Identifying spiritual beliefs;

120. Identifying factors that cause low self-esteem;

121. Facilitating family ability to participate in care plan (10035927);

122. Observing feelings of sadness, irritability, fear, anxiety and loneliness, seeking to offer support;

123. Providing a suitable environment for meals;

124. Providing an adapted environment without obstacles;

125. Teaching techniques to reduce anxiety (relaxation, rest, reading, music therapy);

126. Promoting effective family communication (10036066);

127. Providing an adequate environment (comfortable bed, noise and odor control, lighting and temperature);

128. Providing a calm and safe environment;

129. Providing activities that increase self-esteem (hygiene, reading, music therapy);

130. Providing active communication to interpret the conflict;

131. Providing prayer time;

132. Providing privacy for spiritual behavior (10024504);

133. Providing privacy for religious behavior in bed;

134. Providing routine care so as not to interrupt the person's sleep and rest;

135. Distraction (10039232);

136. Providing alternative techniques for anguish relief (image building, relaxation);

137. Providing techniques to perform spirituality (reading, music therapy);

138. Providing visits by religious entities;

139. Respecting spiritual beliefs;

140. Respecting religious beliefs; 
Chart 1 (concluded)

\begin{tabular}{|c|c|}
\hline & SUPERVISED CARDIOVASCULAR REHABILITATION PROGRAM \\
\hline & Nursing Diagnosis Statement \\
\hline Discon & nfort (Specify Location) (10023066) \\
\hline Increas & sed nocturnal urinary frequency \\
\hline Deficie & ent food intake (10000607) \\
\hline Damag & ged skin integrity (10001290) \\
\hline Decrea & ased intestinal motility \\
\hline Impair & red mobility in bed (10001067) \\
\hline Increas & sed body weight \\
\hline Alterec & d blood pressure (10022954) \\
\hline Risk fo & r impaired skin integrity (10015237) \\
\hline Risk fo & r pressure ulcer (10027337) \\
\hline Risk for & r decreased intestinal motility \\
\hline Impair & red sleep and rest \\
\hline Hypov & /olaemia \\
\hline & Nursing Intervention Statement \\
\hline $\begin{array}{l}141 . \\
142 . \\
143 . \\
144 . \\
145 . \\
146 . \\
147 . \\
148 . \\
149 . \\
150 . \\
151 . \\
152 . \\
153 . \\
154 . \\
155 . \\
156 . \\
157 . \\
158 . \\
159 . \\
160 . \\
161 . \\
162 . \\
163 . \\
164 . \\
165 . \\
166 . \\
167 . \\
168 .\end{array}$ & $\begin{array}{l}\text { Applying elastic stockings (10030486); } \\
\text { Assisting with the search for comfortable body position; } \\
\text { Assisting with mobility in bed (10045972); } \\
\text { Assistance with food in bed; } \\
\text { Assisting with bed/bathroom bath; } \\
\text { Assisting with better positioning for eating in bed; } \\
\text { Assisting with get dressed in bed; } \\
\text { Assisting with oral hygiene in bed every } 6 \text { hours; } \\
\text { Evaluating lower limb edema; } \\
\text { Assessing the need for help in self-care; } \\
\text { Identifying factors that alleviate/worse pain; } \\
\text { Identifying factors that cause pain; } \\
\text { Identifying factors that cause dyspnea; } \\
\text { Skin care (10032757); } \\
\text { Maintaining a sodium-restricted diet for increased blood pressure; } \\
\text { Maintaining intimate hygiene; } \\
\text { Keeping lower limbs elevated; } \\
\text { Keeping skin hydrated; } \\
\text { Keeping skin clean and dry; } \\
\text { Monitoring medication adherence (10043878); } \\
\text { Monitoring person's degree of ability to perform self-care; } \\
\text { Teaching about not eating too hot or too cold food; } \\
\text { Promoting and assisting skin hygiene; } \\
\text { Protecting bony body regions, allowing adequate tissue perfusion; } \\
\text { Providing assistance until the person is fully capable of performing autonomous self-care; } \\
\text { Providing daily body hygiene; } \\
\text { Providing routine times for medication administration together with the person avoiding diuretic medications at night; } \\
\text { Providing exchange of equipment for person's care; Use special mattress (pneumatic, pyramidal) }\end{array}$ \\
\hline & EXERCISE-BASED THERAPY \\
\hline & Nursing Diagnosis Statement \\
\hline Fatigue & e (10000695) \\
\hline Activit & y intolerance (10000431) \\
\hline Impair & red mobility (10001219) \\
\hline & Nursing Intervention Statement \\
\hline $\begin{array}{l}169 . \\
170 . \\
171 . \\
172 . \\
173 . \\
174 . \\
175 . \\
176 . \\
177 . \\
178 .\end{array}$ & $\begin{array}{l}\text { Helping person to stand up and walk around; } \\
\text { Helping person to sit on the edge of the bed for postural management; } \\
\text { Educating about physical exercise regimen; } \\
\text { Encouraging autonomous walking; } \\
\text { Identifying factors that cause fatigue; } \\
\text { Monitoring activity tolerance (10036622); } \\
\text { Teaching light to moderate exercise; } \\
\text { Providing person's body alignment during the transfer technique; } \\
\text { Providing active exercise therapy (walking); } \\
\text { Providing therapy with passive physical exercises (range movements, standing, stretching). }\end{array}$ \\
\hline
\end{tabular}


The nursing diagnosis/outcomes statements were classified in a single column, according to their constancy in the ICNP', noting that the statements contained in the 2019-2020 version of the ICNP ${ }^{\circ}$ are accompanied by the respective classification codes.

A cross-mapping of nursing diagnosis/outcome statements and interventions was carried out with the nursing diagnosis/ outcomes concepts based on ICNP', version 1.0 (first mapping) and with the concepts of ICNP ${ }^{\circ}$, version 2019-2020 (second mapping).

From the first mapping and based on analysis of similarity and scope, 10 (24\%) nursing diagnosis/outcomes statements were classified as constant, with six (60\%) statements being equal and four (40\%) being similar. Also, 32 (76\%) non-constant statements were classified, with eight (25\%) more comprehensive, nine (28\%) more restricted and 15 (47\%) without agreement.

In the second cross-mapping of 42 constructed nursing diagnosis/outcomes statements, 30 (71\%) were classified as constants, with 24 being equal ( $80 \%$ ) and six (20\%) being similar. As not constant, 12 (29\%) nursing diagnosis/outcome statements were classified, six (50\%) being more comprehensive, five (42\%) more restricted and one (8\%) not in agreement with the nursing diagnosis/outcome concepts of the ICNP', version 2019-2020.

The first mapping and analysis of similarity and scope of the constructed nursing intervention statements $(n=179)$ resulted in six (4\%) classified as constant, two being equal (29\%) and four (71\%) similar statements. Therefore, 173 (96\%) were classified as non-constant, 38 (22\%) being more comprehensive, 22 (13\%) more restricted and 113 (65\%) not in agreement with the nursing intervention statements constructed from the ICNP', version 1.0.

In the second mapping of intervention statements, 33 (18\%) were classified as constant, with 10 being equal (30\%) and 23 (70\%) being similar. Thus, 146 statements (82\%) were classified as non-constant, with three (2\%) more comprehensive, 87 (60\%) more restricted and $56(38 \%)$ not in agreement with the concepts of nursing interventions of the ICNP'.

Thus, the proposition of a terminology subset for nursing care for people with heart failure was consolidated, based on the ICNP', version 2019-2020 and Nur-MRT-CVR, subject to content evaluation by experts.

\section{DISCUSSION}

The study presented as relevant data pre-coordinated concepts based on phenomena present in the clinical chart of people with heart failure in secondary and tertiary health care services, i.e., when the condition is decompensated as a technological apparatus of essential importance for systematic and individualized care in cardiovascular care, especially for heart failure.

In this sense, concepts of diagnoses/outcomes and interventions stand out, comprising the four main signs and symptoms of this population, namely dyspnea, edema, tachycardia and pulmonary congestion, which are organized within the Nur-MRT CVR concept, which refers to the fundamental basis for delineating care, from the body of nursing knowledge, especially by an MRT, as it allows a lower level of abstraction of the concepts being studied, which allows to use and apply them in practice.

Dyspnea presents together with cough, due to a decrease in cardiac output, which increases intravascular volume, resulting in edema, the latter being justified by excess fluid, caused by excessive intake of fluids and sodium and, consequently, renal and fluid overload, which results from water retention in the interstitial space, the phenomenon being represented by the increase in body weight as a consequence of this process ${ }^{(16)}$, another phenomenon contemplated in the current study.

In this regard, it is understood the interrelationship between these phenomena in the person with heart failure, as well as the necessary interventions in this process, as evidenced in several studies in the area ${ }^{(16-18)}$. The identification of such phenomena must be carried out based on the monitoring of changes in signs, such as respiratory and heart rate, peripheral oxygen saturation, expectoration, murmurs, noises or other signs, the positioning of people with an elevated headboard and oxygen therapy ${ }^{(16)}$.

The concept "Educational process" has phenomena related to self-care and medication management, the latter being similarly constructed in the first subset for heart failure ${ }^{(9)}$ "lack of adherence to the therapeutic regimen" and "poor response to medication".

The concept "Supervised cardiovascular rehabilitation program" included Impaired Skin Integrity, which was also evidenced in a study on the identification of priority nursing diagnoses for people with decompensated heart failure ${ }^{(19)}$, but using another classification system, the NANDA-International. This aspect demonstrates that the person assisted in tertiary care is prone to such a phenomenon, expressing the potential for the development of this need.

Important nursing interventions in this context, as discussed in the nursing interventions constructed in the current study, are characterized by providing people's skin and body hygiene, according to the institution's routine, keep the person's skin clean, dry and hydrated and supervise the insertion site of invasive devices regarding temperature, color, pain and secretion, converging with the findings in the literature ${ }^{(20)}$.

The phenomena related to the increase in nocturnal urinary frequency and the decrease in urinary volume were covered in another study using the ICNP'(9). The first usually increases at night, with a decrease in energy demand, which improves renal perfusion, which sometimes requires catheterization, with the aim of having fewer nocturnal interruptions in sleep. Urinary volume, on the other hand, tends to decrease during the day, with oliguria due to reduced systolic volume and blood pressure, in addition to the increase in intravascular volume, and interventions are consistent with the assessment of signs of edema, fluid and electrolyte balance, weight and urinary catheterization ${ }^{(21)}$.

The concept "Exercise-based therapy" was characterized by phenomena based on activity intolerance and impaired mobility. A study in the area built a concept similar to that of the present study, "Activity intolerance", based on NANDA-International(19). As interventions aimed at this concept, it is important to help the person to stand up and walk and provide guidance on light to moderate physical exercise regimens in the post-discharge period. Such indications are confirmed in the literature, referring to walking as an important intervention, even referring to an effective improvement in quality of life related to psychological functions such as anxiety ${ }^{(22)}$.

"Fatigue" and "Activity intolerance" were also built in a study about their accuracy in hospitalized people with heart failure, 
ICNP ${ }^{\otimes}$ terminology subset for the care of people with heart failure Nascimento MNR, Gomes EB, Félix NDC, Rebouças CBA, Nóbrega MML, Oliveira CJ.

based on NANDA-International ${ }^{(18)}$. According to the authors, the phenomena of fatigue and activity intolerance, even though they are similar, have common and subjective characteristics, being able to be identified separately in applied clinical cases.

Activity intolerance is justified by the imbalance between oxygen supply and demand. Fatigue, on the other hand, is one of the most prevalent complaints, being generally associated with dyspnea, declining physical and emotional health, depression, insomnia, decreased ejection fraction and worsening of functional class more present in women and beta-blockers users ${ }^{(23)}$.

It is worth noting that $76 \%$ of diagnosis/outcomes statements and $96 \%$ of the intervention statements were classified as not included in the subset constructed based on the ICNP', version $1.0^{(9)}$. In addition, $29 \%$ of diagnosis/outcomes statements and $82 \%$ of nursing intervention statements were considered not included in the ICNP', version 2019-2020, demonstrating the high prevalence of new phenomena included in the care of this population.

Statements not included in the first subset were mainly based on phenomena that included "Psychosocial support for patients and families", such as fear, which has been reported in the literature as a phenomenon linked to anxiety, being present in most cases in this way. simultaneous, almost always related to social limitations, acting on the modification of personal lifestyle habits. Other phenomena present in people with heart failure are low self-esteem, situational and hopelessness, due to greater dependence on others ${ }^{(24)}$.

The care proposed in this study converges with literature data on the phenomenon under study, even though there is not a large number of studies that propose to build nursing diagnoses/ outcomes and interventions as aspects that support the care of people with heart failure.

Thus, a large number of phenomena present in the pathophysiological and socio-spiritual process of heart failure contemplated in the nursing diagnosis statements constructed are found in the literature, however, not in the form of diagnosis concepts based on the use of nursing classification systems, which makes the clinical application of this subset relevant, in order to demonstrate whether such aspects are really useful and thus consolidate this language.

\section{Study limitations}

The need for further studies regarding content and clinical evaluation of this terminology subset stands out to consolidate the knowledge of nursing care for people with heart failure.

\section{Contributions to nursing and health}

The present study is based on the update of the first terminology subset built at the ICNP Brazilian Center as a historical landmark in the consolidation of the classification system in the country, proposing a new tool based on current precepts and standards in force that govern the construction of terminology subsets worldwide. In addition to the advancement of the classification system, there is the consolidation of the body of nursing knowledge, the use of a nursing MRT, the potential to generate nursing indicators, the integration of software for the nursing process in cardiology services, the potential and the development of nursing theories aimed at cardiovascular care at medium and high complexity levels and not just rehabilitation.

\section{FINAL CONSIDERATIONS}

It was possible to construct nursing diagnosis/outcome and intervention statements, organized into five concepts of the theory, highlighting with a higher prevalence of statements the concepts "Rehabilitative care", "Psychosocial support for patients and families", "Supervised cardiovascular rehabilitation program", which supported the elaboration an ICNP terminology subset for people with heart failure in hospital care, based on the Nur-MRT CVR. The perspective for further evaluative studies, both content and clinical, with the respective study population is highlighted, contributing to the clinical evaluation process of Nur-MRT CVR.

\section{FUNDING}

The article was funded by FUNCAP (Fundação Cearense de Apoio ao Desenvolvimento Científico e Tecnológico).

\section{REFERENCES}

1. Chivite D, Franco J, Formiga F. Chronic heart failure in the elderly patient. Rev Esp Geriatr Gerontol. 2015;50(5):237-46. https://doi.org/10.1016/j. regg.2015.03.003

2. Emory Health Care. Heart Failure Statistics [Internet]. 2019[cited 2020 Aug 19]. Available from: https://www.emoryhealthcare.org/heart-vascular/ wellness/heart-failure-statistics.html

3. Oliveira IM, Silva RCG. Comparação do grau de acurácia diagnóstica de graduandos e enfermeiros em programas de residência. Rev Mineira Engerm. 20:e952. https://doi.org/10.5935/1415-2762.20160021

4. Carvalho CMG, Cubas MR, Nóbrega MML. Brazilian method for the development terminological subsets of ICNP®: limits and potentialities. Rev Bras Enferm. 2017;70(2):430-5. https://doi.org/10.1590/0034-7167-2016-0308

5. Garcia TR, organizadora. Classificação Internacional para a Prática de Enfermagem (CIPE®): versão 2019-2020. Porto Alegre: Artmed, 2020.

6. International Council of Nurses. Guidelines for ICNP ${ }^{\circledR}$ catalogue development: international classification for nursing practice (ICNP) programme [Internet]. Geneva: ICN; 2018[cited 2020 Aug 19]. Available from: https://www.icn.ch/sites/default/files/inline-files/Guidelines\%20for\%20ICNP\%20 Catalogue\%20Development\%202018.pdf

7. Primo CC, Resende FZ, Garcia TR, Duran ECM, Brandão MAG. Subconjunto terminológico da CIPE ${ }^{\circledR}$ para assistência à mulher e à criança em processo de amamentação. Rev Gaucha Enferm. 2018;39:e2017-0010. https://doi.org/10.1590/1983-1447.2018.2017-0010 
8. Castro MCF, Fuly PSC, Garcia TR, Santos MLSC. ICNP ${ }^{\oplus}$ terminological subgroup for palliative care patients with malignant tumor wounds. Acta Paul Enferm. 2016;29(3):340-6. https://doi.org/10.1590/19820194201600047

9. Araújo AA, Nóbrega MML, Garcia TR. Nursing diagnoses and interventions for patients with congestive heart failure using the ICNP®. Rev Esc Enferm USP. 2013;47(2):385-92. Portuguese. https://doi.org/10.1590/S0080-62342013000200016

10. Nascimento MNR, Silva MY, Viana MCA, Oliveira CJ, Martins AKL, Félix NDC. Nursing diagnoses for people with heart failure: cross mapping. Rev Enferm UFPE. 2019;13: e240194. https://doi.org/10.5205/1981-8963.2019.240194

11. Farias MS. Reabilitação cardiovascular: proposta de uma teoria de enfermagem de médio alcance [Dissertação]. Abaiara: Universidade Estadual do Ceará; 2018.

12. von Elm E, Altman DG, Egger M, Pocock SJ, Gotzsche PC, Vandenbroucke JP. The strengthening the reporting of observational studies in epidemiology (STROBE) statement: guidelines for reporting observational studies [Internet]. Equator Network; 2007 [cited 2020 Aug 19]. Available from: https:// www.equator-network.org/reporting-guidelines/strobe/

13. Nascimento MNR, Moreira AEA, Ramos NM, Gomes EB, Félix NDC, Oliveira CJ. Specialized nursing terminology for the care of people with chronic heart failure. Esc Anna Nery 2021;25(2):e20200306. https://doi.org/10.1590/2177-9465-EAN-2020-0306

14. International Organization for Sandardization. Health informatics: categorial structures for representation of nursing diagnoses and nursing actions in terminological systems: ISO 18104/2014. Geneva: ISO; 2014.

15. International Organization for Standardization. Health informatics: principles of mapping between terminological systems: ISO ISO 12300/2016. Genebra: ISO; 2016.

16. Sousa MM, Araújo AA, Freire MEM, Oliveira JS, Oliveira SHS. Nursing diagnoses and interventions for people with decompensated heart failure. Rev Pesqui Cuid Fundam. 2016;8(4):5025-31. https://doi.org/10.9789/2175-5361.2016.v8i4.5025-5031

17. Ernandes CM, Bernardes DS, Mantovani VM, Pedraza LL, Rabelo-Silva ER. Prediction of risk and diagnostic accuracy in patients hospitalized for decompensated heart failure: cohort study. Rev Gaucha Enferm. 2019;40:e20180032. https://doi.org/10.1590/1983-1447.2019.20180032

18. Pereira JMV, Cavalcanti ACD, Lopes MVO, Silva VG, Souza RO, Gonçalves LC. Accuracy in inference of nursing diagnoses in heart failure patients. Rev Bras Enferm. 2016;68(4):690-6. https://doi.org/10.1590/0034-7167.2015680417i

19. Galvão PCC, Gomes ET, Figueirêdo TR, Bezerra SMMS. Nursing diagnosis applied to patients with decompensated heart failure. Cogitare Enferm. 2016;21(2):1-8. https://doi.org/10.5380/ce.v21i2.44646

20. Brito JLOP, Pôrto SCAS, Sousa MJF, Sousa Neto VL, Silva RAR. Diagnoses, interventions and outcomes of nursing expected for patients with HIV/AIDS: an integrative review. Rev Bras Cienc Saude. 2017;21(2):165-72. https://doi.org/10.22478/ufpb.2317-6032.2017v21n2.20259

21. Comitê Coordenador da Diretriz de Insuficiência Cardíaca. Diretriz brasileira de insuficiência cardíaca crônica e aguda. Arq Bras Cardiol. 2018;111(3):436-539. https://doi.org/10.5935/abc.20180190

22. Cu X, Dong W, Li H. Collaborative care intervention for patients with chronic heart failure A systematic review and meta-analysis. Medicine (Baltimore). 2019;98(13):e14867. https://doi.org/10.1097/MD.0000000000014867

23. Costa MB, Bandeira GMS, Pereira JML, Figueiredo LS, Cordeiro RG, Flores PVP. Association of international NANDA nursing diagnoses with hospitalization and death in heart failure. Rev Nursing. 2019[cited 2020 Mar 2];22(250):2783-87. Available from: http://www.revistanursing.com.br/ revistas/250/pg78.pdf

24. Souza TCTOA, Correia DMS, Nascimento DC, Christovam BP, Batista DCS, Cavalcanti ACD. The difficult daily life of heart failure bearing patients. Rev Pesqui Cuid Fundam. 2019;11(5):1340-6. https://doi.org/10.9789/2175-5361.2019.v11i5.1340-1346 